\title{
Death Penalty for Corruptors: Between the Human Rights and Challenges of Progress in Indonesian Law
}

\author{
Toba Sastrawan Manik ${ }^{1}$, Sunarso $^{2}$ \\ ${ }^{1}$ Universitas Negeri Yogyakarta, Indonesia, Email: toba0204pasca.2018@student.uny.ac.id \\ ${ }^{2}$ Universitas Negeri Yogyakarta, Indonesia, Email: sunarso@uny.ac.id
}

\section{Article Info}

\section{Keywords: \\ Corruption, Death Penalty, Students.}

How to cite:

Toba Sastrawan Manik, Sunarso, "Death Penalty for Corruptors: Between the Human Rights and Challenges of Progress in Indonesian Law", Fiat Justisia: Jurnal Ilmu Hukum 14, 3 (2020): 233-246.

DOI:

10.25041/fiatjustisia.v14no3.1773
The study concerned here examined students' perceptions of death penalty existence for corruptors. Corruption is a significant problem that captures the attention of the wider public. Corruption has a vast, systematic, and complex impact so that it could be classified as an extraordinary crime. Despite that classification, it turns out that the public considers corruptors' punishment in Indonesia still too light and has not met the public's expectations regarding justice. The people still feel the disparity in a penalty for corruption. The public believes capital punishment to a punishment option that could cause a deterrent effect. The majority of the public wants corruptors to be sentenced to death, but there is opposition to the death penalty on the grounds of upholding human rights. This study was conducted by students of the Pendidikan Pancasila dan Kewarganegaraan (PPKn) or Department of Pancasila and Citizenship, Faculty of Social Sciences, Universitas Negeri Medan. It is found in the study that students agree on the death penalty for corruptors, that they do not see human rights as an excuse for rejecting the death penalty. Moreover, the death penalty is to be viewed as a breakthrough in combating corruption in Indonesia.

\section{A. Introduction}

Corruption is a serious problem in Indonesia. The corruption phenomenon is carried out on a massive scale by many public officials. It is also confirmed 
by Zaidun ${ }^{1}$ saying that, as days increased, the development of corruption in Indonesia has not diminished because, along with the development of regional autonomy, corruption in Indonesia has extended to all regions of the country and evenly distributed all over the regions. Data from the Indonesian Ministry of Home Affairs (Kemendagri) recorded that as of January 2014, there were 318 people out of a total of 524 regional and head deputy regional involved in corruption cases. ${ }^{2}$ Corruption is even referred to as a culture (i.e., corruption as a way of life). ${ }^{3}$

As a country that is familiar with corruption, Indonesia was ranked the $89^{\text {th }}$ out of 180 countries in the world in $2018 .{ }^{4}$ It is indicated that anticorruption enforcement in Indonesia is still weak and slow. One important factor in combating corruption is from the aspect of law enforcement. The enforcement of law refers to efforts made by law enforcement officials to eradicate harmful criminal actions in the country. ${ }^{5}$

Indonesia is a state of law. ${ }^{6}$ Thus, Indonesia respects and executes the law both in vertical (between the state and society) and horizontal (between any society member and another) relations. The term state of the law is a special combined use of two certain words; state and law. It emphasises the form and nature of mutual relation between the state and the law. The state has the purpose of maintaining order in relation to the law (rechtsorde). ${ }^{7}$

Corruption is an act that is against the law. Its affirmation could be seen in the definition of corruption stipulated in Law No. 20 of 2001 in the amendment of Law No. 31 of 1999 concerning Eradication of Corruption, presented by stating that any person who unlawfully commits acts of enriching oneself (or another person or a corporation) that could be detrimental to the country's finances or the country's economy shall be sentenced to life imprisonment or imprisonment for a minimum of 4 (four) years and a maximum of 20 (twenty) years and a minimum fine of Rp.200.000.000,00

\footnotetext{
${ }^{1}$ Dyatmiko Soemodihardjo, Mencegah dan Memberantas Korupsi. Mencermati Dinamika di Indonesia (Jakarta: Pustaka Publisher, 2008), 208.

2 Jpnn.com. (2014). "318 Kepala Daerah Terjerat Korupsi”, Available online form:https://www.jpnn.com/news/318-kepala-daerah-terjerat-korupsi?page=2, accessed August 27, 2019.

${ }^{3}$ H. Siswanto, "Pembangunan Penegakan Hukum Pidana yang Mengefektifkan Korporasi Sebagai Subjek Tindak Pidana korupsi”, Fiat Justisia Jurnal Ilmu Hukum 9, 1 (2015): 1-16, https://doi.org/10.25041/fiatjustisia.v9no1.584.

${ }^{4}$ Transparancy International Indonesia. (2019). ’Indeks Persepsi Korupsi Indonesia 2018 Naik Jadi 38 Poin "available online form:https://nasional.tempo.co/read/1170330/indeks-persepsikorupsi-indonesia-2018-naik-jadi-38-poin/full\&view=ok (accessed August 27,2019.)

${ }^{5}$ M Muchlis, "Penegakan Hukum Terhadap Tindak Pidana Korupsi Dengan Kerugian Negara Yang Kecil Dalam Mewujudkan Keadilan”, Fiat Justisia Jurnal Ilmu Hukum 10, 2 (2016): 221412, https://doi.org/10.25041/fiatjustisia.v10no2.652.

${ }^{6}$ Article 1 (3) Indonesian Consitution 1945.

${ }^{7}$ Majda El Muhtaj, Hak Asasi Manusia dalam Konstitusi Indonesia. Dari UUD 1945 sampai Amandemen UUD 1945 Tahun 2002 (Jakarta: Kencana Prenadamedia Group, 2015), 19-20.
} 
(two hundred million Indonesian Rupiah) and a maximum fine of Rp.1.000.000000,00 (one billion Indonesian Rupiah). ${ }^{8}$

Based on the definition above, the main idea is the massive emergence of new corruptors and also the lack of the law's execution in maintaining justice in the process of law enforcement against corruptors in Indonesia. The public still regards the verdict given to the perpetrators of corruption as not yet fulfilling the public's sense of justice. It is still considered not proportional. One of the reasons is that the verdict given by the panel of judges is still relatively light and disparity often occurs between the verdicts for similar cases. As a result, the punishment for corruptors is inconsistent. ${ }^{9}$

The public expects tougher punishment and even the death penalty in fighting against corruption. According to a survey by the Indonesian Survey Center (ISC), the public expects a deterrent effect as a sanction, hence the death penalty (according to $49.2 \%$ of the respondents), life imprisonment (according to $24.6 \%$ of them), and impoverishment of corruptors (according to $11.3 \%$ of them). ${ }^{10}$ The deterrent effect results in corruptors in fear discouraged or lost interest in committing the crime because of the punishment.

Law No. 20 of 2001 on Eradicating Corruption mentioned the death penalty for corruptors. However, it is restricted to certain circumstances. In Paragraph (2) of Article 2, it is stated that in the case of a criminal act of corruption as referred to in Paragraph (1) being carried out in certain circumstances, the death penalty might be imposed. Certain circumstance is a provision for giving heavier punishment to the perpetrators of corruption if the crime is committed when the country is in danger according to the law, such as when national natural disasters occur, when it is done as a repetition of a criminal act of corruption by the same person, or when the country is in a state of economic and monetary crisis.

The public's desire for corruptors in Indonesia to be sentenced to death is not without opposition from a part of the public itself. These opponents are those who say that the death penalty both for corruptors and for perpetrators of other crimes violates the human rights and the 1945 Constitution of the Republic of Indonesia. ${ }^{11}$ Any decision concerning the matter needs to involve

\footnotetext{
${ }^{8}$ Law No. 20 of 2001 the changes of Law No 31 of 1999 Concerning Eradiction of Corruption, Article 2 (1).

${ }^{9}$ Indonesia Corruption Watch (ICW), Studi atas Disparitas Putusan Pemidanaan Perkara Tindak Pidana Korupsi, (2014), 22.

${ }^{10}$ Indonesia Survey Center, (2014). "Publik Pilih Hukuman Mati untuk Koruptor.” available online form: https://www.liputan6.com/news/read/810134/publik-pilih-hukuman-mati-untukkoruptor?utm_expid=.9Z4i5ypGQeGiS7w9arwTvQ.0\&utm_referrer=https\%3A\%2F\%2Fww w.google.com\%2F. (accessed on August 27,2019).

${ }^{11}$ Hukumonline.com. (2003). "Hukuman mati bagi koruptor, Perlukah?" available online form: https://www.hukumonline.com/berita/baca/hol7486/hukuman-mati-bagi-koruptor-/. (accessed on Agustus, 27, 2019.)
} 
more people. These people include aspiring students as strata in society that has an above-average scholarship. It is encouraged the writers to examine the students' perceptions of corruption in Indonesia, and especially from the point of the students of the Department of Pancasila and Citizenship (PPKn), Social Sciences Faculty, Universitas Negeri Medan.

The research is sociological-juridical. Such research aims at finding facts in society. ${ }^{12}$ The data collection was carried out by using survey methods with observation and questionnaire techniques of data collection. This study involved initially been 147 people and then sampled only 30 people, selected using a purposive/judgmental sampling method with indicators of active in students' organizations and earning the final GPA of 3.00. The data analysis technique used was a simple one using percentage calculations which were then analyzed descriptively quantitatively.

\section{B. Discussion}

\section{Death Penalty}

Capital punishment is not something new in Indonesian criminal law. Otherwise known as the death penalty, it had already existed before the more modern legal system became known. Therefore, the death penalty is familiar as an older punishment. Even so, according to Amnesty International as of December 31,2015, the development of the death penalty globally is divided into four types (related to numbers of countries treating it differently), namely, (1) being abolished for all types of crime: 102; (2) being abolished for only ordinary crimes: 6 ; (3) being abolished in practice: 32 ; (4) being totally abolished in law or practice: 140 ; and (5) being maintained: $58 .{ }^{13}$ Indonesia is among the 58 countries belonging to the category of maintaining the practice of capital punishment in criminal law.

Historically, capital punishment has been known in the archipelago. According to Artiono, ${ }^{14}$ since the Majapahit Kingdom era, the death penalty has been used as a necessary punishment for proven guilty people.

Today, Indonesia still maintains the death penalty in its criminal law. However, the abolition of the death penalty by the Dutch Colonization is not implemented by Indonesia. According to Satochid Kartanegara, ${ }^{15}$ the reasons were based on (a) Indonesia consists of various ethnic groups and there are colonies with a population comprised of various tribes that it is very easy to cause various conflicts between tribes and, to avoid conflicts and their

\footnotetext{
${ }^{12}$ Soejono Soekanto, Pengantar Penelitian Hukum (Jakarta: UI Press, 1982), 10.

${ }^{13}$ Amnesty International, Vonis Hukuman Mati Dan Eksekusi Pada Tahun 2015 (London: Amnesty International Ltd, 2015), 34

${ }^{14}$ Yon Artiono Arbai, Aku Menolak Hukuman Mati. Telaah Atas Penerapan Pidana Mati (Jakarta: Kepustakaan Populer Gramedia, 2012), 15.

${ }^{15}$ Artiono, Loc.Cit., 16
} 
consequences, the death penalty is considered necessary to maintain; (b) Indonesia consists of a large number of islands and at that time the colonial government apparatus was inadequate, in addition to the transportation facilities between islands being also imperfect; and (c) regardless of the reasons related to geographical circumstances, some experts argue that a region with colonies requires absolute power to maintain public order so that it could be accounted for.

In Indonesian criminal law, the death penalty is placed as the chief punishment. It could be seen in Article 10 of the Criminal Code, which divides criminal punishment into two types, namely, (a) the main sentence in the form of the death penalty, imprisonment, confinement, or fine, and (b) an additional punishment in the form of revocation of certain rights, seizure of certain goods, or public announcement of a judge's decision. ${ }^{16}$ The definition of the main punishment, according to Ishaq ${ }^{17}$, is a sentence that is free from other penalties, meaning that it could be handed down to the convicted parties independently. According to Kholiq ${ }^{18}$, in a criminal system, the existence of capital punishment is still legitimized by Section (a) in Article 10 of the Criminal Code. Therefore, the death penalty remains valid as a sanction that one is threatened with for various serious crimes such as

a. The crime aims to harm or murder the president or vice president (Article 104);

b. Inviting foreign countries to invade Indonesia (Paragraph 2, Article 111);

c. Manslaughter the head of a State (Article 140 paragraph 1);

d. Premeditated murder (Article 340);

e. Theft with violence resulting in the death of the victim (Paragraph 4, Article 365).

Outside the Criminal Code, various laws also show a tendency to maintain capital punishment. They are, for example, laws concerning crimes related to narcotics (Law No.22 of 1997) and psychotropics (Law No.5 of 1997), corruption crimes (Law No.31 of 1999 jo. Law No. 20 of 2001), violation towards human-rights crimes (Law No.26 2000), and the crime of terrorism as stipulated in PERPPU (Regulation Substituting for a Law) No. 1 of 2002, passed later into Law No.15 of 2003.

The purpose of the death penalty being imposed in Indonesia, according to Djamali, ${ }^{19}$ is to make the people pay attention to the government's firm avoidance from peace disturbance that is very much feared by the public. With the death penalty, it is hoped that the people would become afraid of

\footnotetext{
${ }^{16}$ Article 10 of the Criminal Code

${ }^{17}$ H. Ishaq, Pengantar Hukum Indonesia (PHI) (Jakarta: Raja Grafindo Persada, 2014), 138.

${ }^{18}$ M. A. Kholiq, "Kontroversi Hukuman Mati dan Kebijakan Regulasinya Dalam RUU KUHP (Studi Komparatif Menurut Hukum Islam)”, Jurnal Hukum 14, No. 2 (2007): 185-209, https://doi.org/10.20885/iustum.vol14.iss2.art1.

${ }^{19}$ Abdoel Djamali, Pengantar Hukum Indonesia (Jakarta: Raja Grafindo Persada, 2011), 187.
} 
committing the crime concerned. The whole community is expected to be afraid of doing it. Thus, there will be no actions of murder or other crimes that could make the perpetrators sentenced to death.

The point is that the application of the death penalty on corruptors has legal reasons and an urgent public need. Even though there is a conflict between the death penalty and the concept of human rights, at least according to the Constitutional Court, the death penalty is legal in Indonesia. ${ }^{20}$

\section{Corruption in Indonesia}

According to Wattimena, ${ }^{21}$ etymologically, the word corruption comes from a Latin word, namely, corruptus (damaging or destroying). Furthermore, according to Aristotle, corruption is synonymous with two things; death and moral decadence, which then Aristotle equated with hedonism or the way of life whose primary purpose is to seek physical favours alone. ${ }^{22}$ From the point of social pathology, Kartono ${ }^{23}$ defines corruption as follows:

"Corruption is the behaviour of individuals who use authority and position is used to extract personal gain, harming public and state interests". So, corruption is a symptom of power misuse and mismanagement for personal gain and mismanagement of state wealth by using formal authority and powers (for example, with legal reasons and the power of weapons) to enrich themselves.

Legally, the definition of corruption is implied in the phrase as follows: anyone who unlawfully commits acts of improving oneself (or another person or a corporation) that could harm the country's finances or the country's economy. ${ }^{24}$ This expression is sufficient to emphasise corrupt behaviour.

The cause of the corruption strengthening and becoming massive in Indonesia needs to be explored in more depth because of its essential relevance in the formulation of policymaking to eradicate it. The corruption which is so widespread and so easy to occur in Indonesia, according to Andi Hamzah ${ }^{25}$, is caused by (a) insufficient salary or income of the civil servants in comparison with the needs that are increasingly on the rise; (b) the Indonesian cultural background which serves as source or cause of widespread corruption; (c) poor management and less effective and efficient controls; and (d) modernisation.

\footnotetext{
${ }^{20}$ Magazine of Mahkamah Konstitusi (2015)

${ }^{21}$ Wattimena A. A, Filsafat anti Korupsi (Jakarta: Kanisius, 2012), 8.

${ }^{22}$ Ibid., 9

${ }^{23}$ Kartini Kartono, Patologi Sosial, (Jakarta: Raja Grafindo Persada, 2009), 90.

${ }^{24}$ Law Number 20 of 2001 changes to Law No. 31 of 1999 in Article 2 paragraph (1).

${ }^{25}$ Hamzah dalam Jawade Hafidz Arsyad, Korupsi dalam Perspektif HAN (Hukum Administrasi Negara) (Jakarta Timur: Sinar Grafika, 2013), 11-14.
} 
Opinions of other figures are almost similar. Syamsuddin ${ }^{26}$ finds that factors that trigger or cause criminal acts of corruption are (a) weak religious, moral, and ethical education; (b) lack of strong sanctions for corrupt behaviour; (c) the absence of a transparent governance system (good governance); (d) economic factors (in some countries, low salaries of public officials often cause corruption to become a "culture"), (d) poor management and lack of effective and efficient supervision, and (e) the modernization that causes a shift in the values of life that develop in society. ${ }^{26}$ It could be said that the consequences above are immaterial or calculated more to be of the aspect of morality. In addition to the above effects, of course, corruption also takes a lot from state finances which should be used for national development and public interest.

\section{Corruption and the Death Penalty?}

The findings of this study are that $90 \%$ of the respondents say that they understand and have followed the development of corruption in Indonesia and all (or 100\%) of them say that Indonesia is already in an alarming state of corruption and $93.34 \%$ of them say that the roots of the corruption are strong. This study also finds that $90 \%$ of the respondents consider that anti-corruption enforcement is still weak and not optimum. So $70 \%$ of the respondents agree that the sentence given for committing corruption has not fully provided a deterrent effect.

Respondents choose the choice of capital punishment for corruptors, with a percentage of $70 \%$. Of the $70 \%$ (19 respondents), $84.21 \%$ are very sure that the death penalty would have a deterrent effect and the rest stated that they are unsure, but for them, there is no choice other than the death penalty in Indonesia. The reason for refusing the death penalty on the ground of human rights is not too significant, expressed by only $50 \%$ of the respondents. Other reasons are the lack of any guarantee of the death penalty as a solution (as expressed by $25 \%$ of the respondents) and the need for other alternatives (as also expressed by $25 \%$ of the respondents). It is quite interesting because the reasons for refusing capital punishment are not absolutely considerations related to human rights.

According to Gundar $\mathrm{Myrdal}^{27}$, corruption in South and Southeast Asia stems from the disease of neo-patrimonialism, which is the feudal legacy of kingdoms accustomed to patron clients. In this context, the people or subordinates are obliged to give "tributes" (developing into "envelopes", bribes, commissions, etc.) to the holders of power or superiors (bosses, officials, etc.). Syed Hussein Alatas gives a similar view ${ }^{28}$ in stating that

\footnotetext{
${ }^{26}$ Aziz Syamsuddin, Tindak Pidana Khusus (Jakarta: Sinar Grafika, 2011), 15.

27 See in S Didin Damanhuri, Korupsi, Reformasi Birokrasi dan Masa Depan Ekonomi Indonesia, (Jakarta.: Fakultas Ekonomi Universitas Indonesia, 2006), 9.

${ }^{28}$ Ibid.
} 
corruption in Asia is related to the historical-structural inheritance that has been running for centuries due to the repression carried out by the colonizers.

From the opinions of some of the figures above, one could conclude that corruption has entered the level of mentality and even become "entrenched" like a culture in the lives of the Indonesian people specifically. And that is complemented with the current development of modernization as mentioned above, is one of its causes. Corruption is getting increasingly stronger, lasting, and embedded in the minds of the people. With this consideration as a basis, corruption is classified as an extraordinary crime.

It turns out that, although classified as an extraordinary crime, in reality, the enforcement of anti-corruption and the eradication of corruption seem ordinary. Extraordinary measures and extraordinary legal instruments should be applied to corruption. ${ }^{29}$ The public still considers the verdict on corruption not fair and not yet proportional. It is indicated by the relatively light decision of the judge's verdict, and often there is even a disparity in the verdict. So there is inconsistency in the punishment for corruptors. ${ }^{30}$

According to ICW, in quantity, the sentences of less than 4 years in length given for corruption reach $76.8 \%$ (as convictions of 546 defendants), with $39 \%$ (or 231) of them being sentenced to 1-year imprisonment. Sentences of 4 years or more compose as much as $23.3 \%$ (as convictions of 138 defendants), with 91 of the 138 defendants being sentenced to 4-years imprisonment. So, according to ICW, the average rate of the sentences handed down by the court is around two years and three months in prison. ${ }^{31}$

It is confirmed that there are logical and empirical reasons for the public wanting capital punishment for corruptors. The majority of the public considers that the conventional sentence of imprisonment is ineffective and does not have a deterrent effect on corruptors; most members of the public request that corruptors be put to death not only within certain circumstances. Considerations of human rights or Hak Asasi Manusia are ruled out because there are no other options for the relatively entrenched state of corruption in Indonesia.

From the point of existence, tendencies, and systemic impacts, there are truth and logical reasons why the death penalty is appropriate for corruptors. But, from the point of humanistic considerations, matters concerning human rights should still be paid attention to. Nevertheless, there should still be a final decision. There are no grey areas in fighting corruption.

In the Law of the Criminal Act of Corruption, there is a threat of capital punishment, but it is, as previously said, limited to certain circumstances. In

\footnotetext{
${ }^{29}$ Edi Yuhermansyah, Zaziratul Fariza, "Pidana Mati Dalam Undang-Undang Tindak Pidana Korupsi (Kajian Teori Zawajir dan Jawabir)", Legitimasi 1, 1 (2017), 156-174, https://doi.org/10.22373/legitimasi.v6i1.1848.

${ }^{30}$ Indonesia Corruption Watch (ICW), (2014), 22.

${ }^{31}$ Ibid.
} 
Paragraph (2) of Article 2, it is stated that, in the event that a criminal act of corruption as referred to in Paragraph (1) is carried out in certain circumstances, the death penalty might be imposed. It means that the criminal act of corruption merits the death penalty if the act is committed in the circumstance of the country is in danger according to the law in effect, of a national natural disaster being in occurrence, of the act being a repetition of a criminal act of corruption by the same person, or of the country is in a state of economic and monetary crisis.

If you follow the limits mentioned in the explanation, it could be as certain that it is difficult for corruptors to be sentenced to death because the law does not provide clear limits and criteria and even becomes a barrier to corruptors being sentenced to death. Table ${ }^{32}$ argues as follows.

One of the reasons for not applying the death penalty on corruptors is that conditions follow the formulation of the death penalty in "certain circumstances" (Paragraph (2), Article 2). In the explanation of this Article, it is formulated that what is meant by conditions of "certain circumstance" in this provision is intended to make the burden heavier for perpetrators of corruption if the crime is committed when the state is in danger in accordance with applicable law when a national natural disaster occurs when it is a repetition of an act previously done by the same person, or when the country is in a state of economic and monetary crisis.

Limiting the death penalty for corruptors to only certain circumstances, according to Artidjo Alkostar, ${ }^{33}$ is even contradictory to the eradication of corruption because the parameters are unclear. To have clear and measurable parameters, according to Busyro Muqodas ${ }^{34}$, the three main criteria that could make corruptors deserve capital punishment are, namely, (a) the corruption is of more than Rp. 100 billion, causing massive public loss; (b) the corruption is committed by state officials, and (c) the corruption is repeatedly carried out. It could be seen that not only the general public but also legal experts want corruptors to be put to death. According to Anjari, ${ }^{35}$ the criteria for the determination of the death penalty for perpetrators of crimes is by (1) going beyond humanitarian limits, (2) harming and threatening many humans, (3) damaging the nation's generation, (4) damaging the nation's civilization, (5) damaging the order on earth, and (6) harming and destroying the country's economy. Corruption, according to him, is one of the criminal offences that deserve a death sentence. So, to have a benchmark for law enforcers in interpreting how much state losses could be sanctioned with a death sentence,

\footnotetext{
${ }^{32}$ R. M. Toule, E. "Eksistensi Ancaman Pidana Mati dalam Undang-Undang Tindak Pidana Korupsi”, Jurnal Hukum Prioris 3, No. 3 (2013). 103-110.

${ }^{33}$ Ibid., 106.

${ }^{34}$ Ibid., 106.

${ }^{35}$ WAnjari, "Penjatuhan Pidana Mati Di Indonesia Dalam Perspektif Hak Asasi Manusia”, EJurnal Widya Yustisia, 1, No. 2 (2015): 107-115.
} 
the Law of the Corruption Criminal Act should be explicitly formulated more broadly in relation with capital punishment. ${ }^{36}$

\section{Death Penalty for Legal Progressiveness?}

There is an agreement concerning the statement that corruption is an extraordinary crime and that the form of the punishment is to be also analogously extraordinary. It means that in eradicating corruption in Indonesia, progressive legal steps are needed. Progressive law is a significant breakthrough and/or progressive interpretation of the law. According to Rahardjo, progressive law is the law that is affirmative rather than submissive. Being affirmative here refers to the occurrence of the courage to conventionally carry out liberation and emphasize the use of other methods, which is often called a breakthrough. ${ }^{37}$ Rahardjo stressed the importance of judges and prosecutors daring to read texts freely and progressively by placing them in context according to current social conditions and social goals. ${ }^{38}$

The view of legal progressiveness is very much in accordance with the reality of corruption practices. To further strengthen the pros for the death penalty for corruptors, the International Human Rights instrument formulation in the ratification of the ICCPR, in reality, opens contextual and social-interest considerations as a justification for corruption eradication by enforcing the death penalty for the most serious crimes and bypassing the highest judicial series. ${ }^{39}$ The Constitutional Court confirmed the same thing by stating that the opportunity and agreement to apply the death penalty contained in Paragraph (2) of Article 6 are only for special and serious crimes. ${ }^{40}$

If we honestly analyze and consider the motivations and manifestations of corruption in Indonesia, debate on the legal principles regarding the acceptance of the death penalty for corruptors is no longer necessary. It could not be other than the policy of legal progressiveness in Indonesia to include the imposition of capital punishment for corruptors. If we continue to be trapped in debates on principles, then corruption would have no end.

The death penalty for corruptors is interesting to think about and to discuss in depth. It should involve all vital elements of the nationality, including students who have a big part in continuing the life of the nation.

\section{Conclusions}

\footnotetext{
${ }^{36}$ Denny Latumaerissa, "Tinjauan Yuridis Tentang Penerapan Ancaman Pidana Mati dalam Tindak Pidana Korupsi”, Jurnal Sasi 20, No. 1 (2014): 8-18.

${ }^{37}$ Satjipto Rahardjo, Hukum Progresif Sebuah Sintesa Hukum Indonesia (Yogyakarta: Genta Publishing, 2009), 142.

${ }^{38}$ Ibid., 144.

${ }^{39}$ Law No. 12 of 2005 ratification of the International Covenant on Civil and Political Rights (ICCPR), Article 6 paragraph (2).

${ }^{40}$ Hwian Christianto, "Tata Cara Pelaksanaan Pidana Mati bagi Terpidana Mati dalam Hukum Pidana," Jurnal Konstitusi 1, No. 9 (2009): 25-38.
} 
The death penalty for corruptors creates a dilemma both academically and sociologically. Academically, the death penalty for corruptors might be applied but still in a minimal way. Considerations of human rights also become important considerations. However, human-rights considerations are not completely wholesome. Some academics agree with the death penalty for corruptors because it is juridical permitted by the Indonesian legal system. Sociologically, the death penalty for corruptors is desired by the public, which includes the subjects of this research from the students' circles. The fact that the level of corruption is massive, but the sentences handed down by the judiciary are weak urges people to expect the death penalty. Legal progressiveness has become a new alternative study for the Indonesian legal world to bridge the facts about corruption and people's aspirations.

\section{Acknowledgements}

The writers thank Dr. Sunarso, M. Si as a lecturer in the subject of Human Rights and Democracy Education who encouraged rewriting about the death penalty and corruption in Indonesia and also helped to provide input and references. The writers' thanks are likewise expressed to Dra. Yusna Melianti, M. Hum, who was greatly involved and importantly so in the initial writing about the theme concerned.

\section{References}

A, Wattimena. Filsafat Anti Korupsi. Jakarta: Kanisius, 2012.

Amnesty International. Laporan Global Amnesty International: Vonis Hukuman Mati dan Eksekusi Pada Tahun 2015. London: Amnesty International, Ltd, 2015.

Anjari, W. "Penjatuhan Pidana Mati di Indonesia Dalam Perspektif Hak Asasi Manusia." E-Jurnal Widya Yustisia 1, No. 2 (2015).

Arsyad, Jawade Hafidz. Korupsi dalam Perspektif HAN (Hukum Administrasi Negara). Jakarta Timur: Sinar Grafika, 2013.

Artiono Arbai, Yon. Aku Menolak Hukuman Mati. Telaah Atas Penerapan Pidana Mati. Jakarta: Kepustakaan Populer Gramedia, 2012.

Christianto, Hwian. "Tata Cara Pelaksanaan Pidana Mati Bagi Terpidana Mati dalam Hukum Pidana.” Jurnal Konstitusi 1, No. 9 (2009).

Djamali, Abdoel. Pengantar Hukum Indonesia. Jakarta: Raja Grafindo Persada, 2011.

Dyatmiko. Mencegah dan Memberantas Korupsi. Mencermati Dinamika di Indonesia. Jakarta: Pustaka Publisher, 2008.

El, Muhtaj, Majda. Hak Asasi Manusia dalam Konstitusi Indonesia. Dari UUD 1945 Sampai Amandemen UUD 1945 Tahun 2002. Jakarta: Kencana. Prenada Media Group, 2015. 
Hukumonline.com. (2003). "Hukuman mati bagi koruptor, Perlukah?" available online form: https://www.hukumonline.com/berita/baca/hol7486/hukuman-matibagi-koruptor-/. accessed on August 27, 2019.

Indonesia Criminal Code (KUHP).

Indonesia Survey Center (2014). "Publik Pilih Hukuman Mati untuk Koruptor" available online form: https://www.liputan6.com/news/read/810134/publik-pilih-hukumanmati-untuk-koruptor (accessed on August 27, 2019).

Indonesian Corruption Watch (ICW). Studi Atas Disparitas Putusan Pemidanaan Perkara Tindak Pidana Korupsi, 2014.

Ishaq, H. Pengantar Hukum Indonesia (PHI). Jakarta: Penerbit Raja Grafindo Persada, 2014.

Jpnn.com. (2014) "318 Kepala Daerah Terjerat Korupsi," available online form: $\quad$ https://www.jpnn.com/news/318-kepala-daerah-terjeratkorupsi?page=2 Accessed on August 27, 2019.

Kartono, Kartini. Patologi Sosial. Jakarta: Raja Grafindo Persada, 2009.

Kholiq, M.A. "Kontroversi Hukuman Mati dan Kebijakan Regulasinya Dalam RUU KUHP (Studi Komparatif Menurut Hukum Islam).” Jurnal Hukum 14, No. 2007 ), https://doi.org/10.20885/iustum.vol14.iss2.art1.

Latumaerissa, Denny. "Tinjauan Yuridis Tentang Penerapan Ancaman Pidana Mati Dalam Tindak Pidana Korupsi.” Jurnal Sasi 20, No. 1 (2014).

Law No. 12 of 2005 Ratification of the International Covenant on Civil and Political Rights (ICCPR).

Law No. 20 of 2001 amendments to Law No. 31 of 1999 concerning Eradication of Corruption Crimes.

Muchlis, Ahmad. "Penegakan Hukum Terhadap Tindak Pidana Korupsi Dengan Kerugian Negara yang Kecil dalam Mewujudkan Keadilan." Fiat Justisia Jurnal Ilmu Hukum 10, No. 2 (2016), https://doi.org/10.25041/fiatjustisia.v10no2.652.

Rahardjo, Satjipto. Hukum Progresif Sebuah Sintesa Hukum Indonesia. Yogyakarta: Genta Publishing, 2009.

S Damanhuri, Didin. Korupsi, Reformasi Birokrasi dan Masa Depan Ekonomi Indonesia. Jakarta: Lembaga Penerbit Fakultas Ekonomi Universitas Indonesia, 2006.

Siswanto, H. "Pembangunan Penegakan Hukum Pidana yang Mengefektifkan Korporasi Sebagai Subjek Tindak Pidana Korupsi.” Fiat Justisia Jurnal Ilmu Hukum 9, No. 1 (2015), https://doi.org/10.25041/fiatjustisia.v9no1.584.

Soekanto, Soejono. Pengantar Penelitian Hukum. Jakarta: UI Press, 1982. Syamsuddin, Aziz. Tindak Pidana Khusus. Jakarta: Sinar Grafika, 2011. 
Toule, E. R. M. "Eksistensi Ancaman Pidana Mati dalam Undang-Undang Tindak Pidana Korupsi”, Jurnal Hukum Prioris 3, No. 3 (2013).

Transparancy International Indonesia. (2019). "Indeks Persepsi Korupsi Indonesia 2018 Naik Jadi 38 Poin" available online form: https://nasional.tempo.co/read/1170330/indeks-persepsi-korupsiindonesia-2018-naik-jadi-38-poin/full\&view=ok (accessed on August 27, 2019).

Yuhermansyah, Edi \& Zaziratul Fariza. "Pidana Mati Dalam Undang-Undang Tindak Pidana Korupsi (Kajian Teori Zawajirdan Jawabir)". Legitimasi 1, No. 1 (2017), https://doi.org/10.22373/legitimasi.v6i1.1848. 
